\title{
KORELASI PENDIDIKAN QURBAN TERHADAP TINGKAT RELIGIUSITAS SISWA (Studi Kasus SMP Agus Salim Semarang)
}

\author{
Imanda Firmantyas Putri \\ Institut Agama Islam Negeri (LAIN) Surakarta \\ Imandaf_putri@ymail.com
}

\begin{abstract}
One of the main pious rituals in Islam is udhiyyah or qurban. Children and adolescents who do not have their own income, actually are not requested to do qurban, because one of the requirements legitimated to do qurban is people who would do it should be able to provide the slaughtered animals. However, education and understanding of the importance of qurban in Islam are very necessary given to them at their young age. This study aimed to see whether there is a correlation between early education given about qurban to the cbildren's level of religiosity. Taking place in SMP Agus Salim Semarang, with population of 467 students, and sample of 82 students, this study used random sampling methods. This research is a field research with the data collection was by questionnaire, observation, interviews, documentation and literature study. The result obtained from this study is the evidence of the hypothesis that there is a significant positive relationship between education about qurban to the religiosity level of students.
\end{abstract}

Keywords: Qurban, Students, Religiosity, Early Education

\begin{abstract}
Abstrak
Salah satu amal salih yang utama didalam ajaran Islam adalah udbiyyah atau berqurban. Anak-anak dan remaja yang belum memiliki pendapatan sendiri, belum disunnabkan untuk berqurban, karena salah satu syarat sab berqurban adalab orang yang berqurban barus mampu untuk. menyediakan bewan sembeliban.Namun, pendidikan dan pemahaman mengenai arti pentingnya qurban dalam Islam sangat perlu diberikan kepada mereka sedari dini.Penelitian ini bertujuan untuk melibat apakah terdapat korelasi antara pendidikan qurban pada anak yang diberikan mengenai qurban dengan tingkat religiusitas anak, dalam hal ini siswa SMP. Mengambil tempat penelitian di SMP Agus Salim Semarang, dengan jumlah populasi 467 siswa, dan sample sebanyak 82 siswa, penelitian ini menggunakan metode simple random sampling. Penelitian ini merupakan penelitian lapangan, dimana pengumpulan datanya adalab dengan teknik kuesioner, observasi, interview, dokumentasi dan studi kepustakaan. Hasil yang diperoleh dari penelitian ini adalah terbuktinya hipotesis yang menyatakan bahwa terdapat bubungan positif signifikan antara pendidikan qurban dengan tingkat religiusitas siswa.
\end{abstract}

Kata Kunci: Qurban, Anak-anak, Religiusitas, Pendidikan Dini 


\section{Pendahuluan}

Islam adalah agama mayoritas di Indonesia.Jumlah penduduk Indonesia yang lebih dari 200 juta jiwa konon 80 persen-nya lebih menganut agama Islam.Di tingkat dunia, beberapa media mengklaim jumlah penganut Islam di Indonesia adalah yang terbesar di dunia. Bahkan bedasarkan hasil penelitian Pew Research Center, Amerika Serikat, dalam sebuat berita yang dimuat tempo.co pada 5 april 2015, di tahun 2070 Islam akan menjadi agama terbesar yang dianut penduduk Bumi.

Pada bulan Oktober tahun 2009 di Woshington DC, the Pew Research Center's Forum on Religion \& Public LifeMapping TheGlobal MuslimPopulation A Report on the Size andDistribution of the World'sMuslim Population merilis penelitiannya yang secara gamblang menyebutkan betapa sungguh sangat dominannya jumlah muslim di Indonesia (www.pewforum.org).

Jumlah yang sedemikian massif, khususnya di Indonesia tentu banyak memberikan kenyamanan kepada para pemeluknya di negara ini. Sebut saja bagaimana bulan Ramadhan terasa begitu meriah, atau bagaimana disetiap waktu sholat, adzan akan bersahut-sahutan berkumandang dari banyak masjid di linkungan sekitar. Kondisi ini seharusnya menjadi ideal dalam menciptakan masyarakat madani sebagaimana yang telah dicontohkan oleh Rasulullah.Namun demikian sesungguhnya dibalik jumlah dominan itu, masih sangat banyak pekerjaan rumah yang harus diselesaikan agar Islam tidak hanya secara resmi tertulis di mayoritas KTP penduduk Indonesia, tetapi juga di implementasikan dalam keseharian masyarakatnya. Didalam Al Qur'an Allah berfirman:

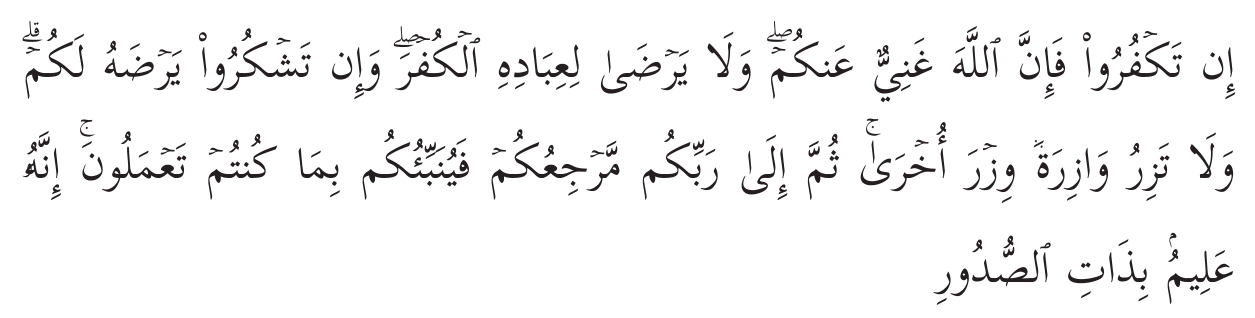


Jika kamu kafir Maka Sesungguhnya Allah tidak memerlukan (iman)mu dan Dia tidak meridhai kekafiran bagi hambaNya; dan jika kamu bersyukur, niscaya Dia meridhai bagimu kesyukuranmu itu; dan seorang yang berdosa tidak akan memikul dosa orang lain. kemudian kepada Tuhanmulah kembalimu lalu Dia memberitakan kepadamu apa yang telah kamu kerjakan. Sesungguhnya Dia Maha mengetahui apa yang tersimpan dalam (dada) mu. (QS. Az Zumar: 7)

Tentu akan sangat sulit mengukur ketebalan akidah setiap individu, tetapi setidaknya dari akhlak yang terlihat, bisa di asumsikan dengan lebih baik seberapa tinggi nilai kesalihan sosial seseorang. Secara nyata, ketika media seakan berlomba-lomba memberitakan betapa bobroknya moral para pemimpin dinegeri ini dengan maraknya pemberitaan kasus korupsi, maka seyogyanya harus segera dilihat bahwa mungkin ada yang harus ditinjau kembali dari kualitas pemahaman agama dari para pemeluknya.

Lepas dari media, dalam kegiatan sehari-hari cukup mudah untuk menemukan banyak kasus pelanggaran lalu-lintas atau sekedar orang yang membuang sampah sembarangan. Keprihatinan ini tidak behenti, karena terjadi ditengah-tengah masyarakat yang nyaring menyuarakan jargon-jargon semacam "kebersihan adalah sebagian dari iman," "man jadda wajada," atau "qulil haqqo walaukana murron.' Keprihatinan ini berlanjut karena bahkan dalam kondisi kritis, sebagian masyarakat tetap berlaku berkebalikan dengan keimanannya.Sebagai contoh, sebagian masyarakat didaerah banjir yang masih membuang sampah disungai dengan ringan dan tanpa merasa berdosa.Dan masih banyak contoh lainya.

Pertentangan jargon dan kenyataan dilapangan inilah yang kemudian memudahkan kita untuk melihat perlunya pembaruan dalam memberikan pemahaman agama kepada masyarakat. Ada sebuah kutipan popular dari Muhammad Abduh, seorang tokoh pembaruan Islam: "aku pergi ke barat dan menemukan Islam, tapi tidak ada umat Islam."Hal ini seakan menampar siapapun, sehingga kebutuhan umat Islam saat ini memang tidak bisa berhenti hanya pada menang jumlah, namun juga harus berat dalam timbangan kualitas. 
P. J. Vatikiotis dari Indiana University mengatakah bahwa dalam pemikirannya, Muhammad Abduh ingin menjembatani antara Iman dan kehidupan nyata seseorang: making possible the belief in a transcendent God to be reflected in man's active life of endeavour towards higher goal. What disturb Muhammad Abduh was the disconecction between social action and religious belief. (Vatikiotis P. J. :1957)

Entah dibagian mana yang salah, tetapi keuntungan "menang jumlah" ini akan sangat sayang jika tidak digunakan untuk memperbaiki bobot penerapan pemahaman ke-Islam-an umat di Indonesia. Sebenarnya jika umat betul-betul memahami dan menerapkan agama Islam dengan sederhana, seharusnya kayakinan dan pengertian itu akan mampu berkontribusi guna memperbaiki bangsa. Dan bisa jadi, penerapan keimanan dalam kehidupan nyatalah yang justru akan menjadi solusi dari masalah-masalah negara ini secara secara tuntas.

Misalnya saja, bagaimana konsep zakat, infaq dan sedekah dapat digunakan untuk menyelesaikan masalah kemiskinan di negeri yang konon kaya raya ini.Khususnya zakat, karena lebih mudah diukur dan hukumnya wajib bagi yang mampu dan memenuhi syarat,tidak terbayangkan betapa besar potensi yang dimiliki zakat dari seluruh rakyat Indonesia untuk mengentaskan kemiskinan. Tentu akan ada kendala disana-sini jika dilakukan saat ini, tetapi jika berhasil dipahamkan, konsep Islam yang "rahmatan lil aalamiin" akan terwujud nyata dalam bentuk pengentasan kemiskinan di Indonesia.

Contoh lain adalah bagaimana memahamkan konsep qurban agar tidak hanya menjadi perayaan makan yang berlebih-lebihan atau bisa jadi justru menjerumuskan kepada perilaku syirik. Qurban dalam kehidupan nyata adalah bagaimana manusia dapat berserah dan berbagi kepada yang membutuhkan.Sebagaimana di firmankan oleh Tuhan dalam surat Al Hajj ayat 34:

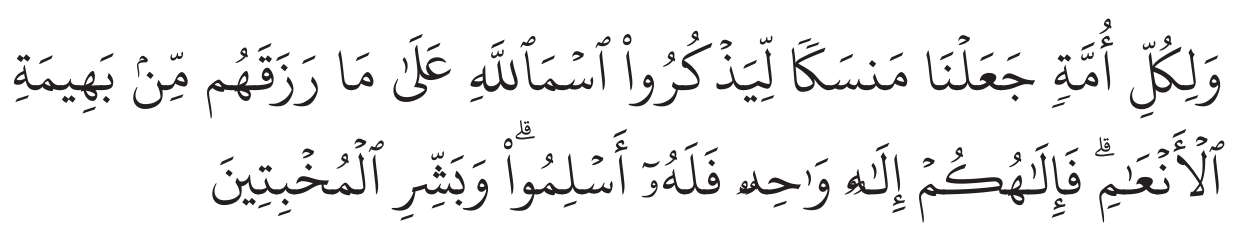


Dan bagi tiap-tiap umat telah Kami syariatkan penyembelihan (kurban), supaya mereka menyebut nama Allah terhadap binatang ternak yang telah direzkikan Allah kepada mereka, Maka Tuhanmu ialah Tuhan yang Maha Esa, karena itu berserah dirilah kamu kepada-Nya. dan berilah kabar gembira kepada orang-orang yang tunduk patuh (kepada Allah).(Qs. Al Hajj:34)

Merujuk pada paragraf-paragraf diatas, tampaknya sekolah menjadi salah satu pilihan yang logis untuk memahamkan konsepkonsep diatas sejak dini.Jikalaupun saat ini terlalu tidak masuk akal untuk diterapkan, setidaknya dengan mendidik-kan siswa di usia dini dengan konsep ke-Islaman-an yang baik dan optimal, maka generasi penerus ini akan mempercepat terciptanya keimanan yang prima, lengkap dengan pengamalan yang berdampak nyata bagi masyarakat. Lebih lanjut, dengan mengajarkan agama dan penerapannya sejak dini, anak-anak akan menyerapnya ke dalam alam bawah sadar (subconscious)-nya sehingga kelak ketika dewasa akan jauh lebih mudah mempraktikkan dan mempengaruhi orang lain untuk melakukan hal yang sama.

Meski merupakan fakta yang agak pahit, tapi selain jumlah jam resmi yang digunakan untuk mengajarkan pengatahuan agama untuk siswa memang sangat kurang, pemahaman yang mendalam juga seharusnya lebih ditekankan lagi agar proses belajar agama tidak sekedar transfer knowledge. Penyampaian materi tidak berarti harus ditinggalkan, hanya melatih untuk membiasakan praktik nya juga perlu dirumuskan dan diajarkan dengan metode yang terbaik, sehingga nilai-nilai ke Islaman dapat lebih dihayati dan diamalkan oleh siswa.

Oleh karena itu, penelitian yang berjudul "Korelasi Pendidikan Qurban Terhadap Religiusitas Siswa" ini pada dasarnya ingin mengungkapkan bagaimana pendidikan qurban diajarkan kepada siswa, dan apakah pendidikan praktik secara langsung ini berdampak terhadap religiusitas para siswa yang terlibat didalamnya.Dengan mengukur tingkat religiusitas siswa, diharapkan, jika hasilnya positif, kegiatan dan sistem pembelajaran yang serupa, dapat di terapkan di tingkat pendidikan yang lain atau disekolah yang lain. Hal ini tentu 
saja akan semakin mempercerahmasadepan bangsa dan agama, karena generasi penerus adalah tunas-tunas yang Islami dan mampu menerapkan nilai-nilai ke Islamannya dalam semua aspek kehidupan.

Penelitian ini dilakukan disebuah SMP umum di kota Semarang yang dipandang memiliki keunikan, sehingga dipilihlah sekolah ini sebagai lokasi penelitian.Sekolah yang dimaksud adalah SMP Agus Salim Semarang, sekolah kecil ini unik, karena aroma keislaman sangat tajam tercium dalam sistem pendidikan yang dianutnya, meski bukan madrasah tsanawiyah, maupun SMP Islam Terpadu. Dalam kesehariannya di sekolah, nilai-nilai ke Islam-an sangat kentaldalam penerapannya di sekolah.

Keunikan yang dirasa sesuai dengan tema penelitian ini adalah salah satu kebiasaan bahwa di setiap hari Jumat, ketua kelas akan berkeliling ke meja teman-temannya untuk memberikan opsi untuk memberikan infaq yang akan digunakan untuk berlatih berkurban pada perayaan hari Idul Adha. Guru selalu menerangkan bahwa ini adalah proses latihan, sambil secara mendetail memberitahu bagaimana tata cara qurban yang sesungguhnya. Pada proses penggalangan dana setiap Jumat inilah siswa betul-betul dibebaskan untuk berpartisipasi atau tidak. Jumlahnya pun bervariasi, dari ribuan hingga ratusan rupiah. Dan singkatnya setelah mendekati hari raya kurban, uang yang terkumpul akan ditambahkan oleh pihak sekolah sehingga dapat dibelikan kambing atau sapi yang kemudian dibagikan kepada para siswa dan masyarakat sekitar yang membutuhkan.

Dalam setiap detail kegiatan ini siswa dilibatkan secara aktif sehingga dapat menghayati esensi dari perayaan dan ibadah qurban. Yang lebih menarik, adalah umumnya pada hari-H perayaan akan ada beberapa walimurid yang juga menambahkan beberapa ekor kambing untuk disembelih setelah sholat Ied berjamaah di lapangan sekolah. Mengingat sekolah ini mayoritas siswanya hidup didalam keluarga dengan kemampuan ekonomi menengah kebawah, sehingga pengajaran dan penerapan pendidikan qurban kepada siswa SMP menjadi tantangan tersendiri bagi pihak sekolah.

Kondisi ini merupakan tantangan yang harus dijawab bersama, bukan hanya oleh pihak sekolah saja. Sehingga penelitian 
ini dilakukan untuk menjawab rumusan masalah: (1). Apakah terdapat korelasi antara pendidikan mengenai qurban dengan tingkat religiusitas siswa SMP, (2). Apabila terdapat korelasi antara keduanya, maka bagaimanakah konsep ini menjadi rumusan tertentu yang dapat diadopsi oleh sekolah lainnya.

Diharapkan apabila konsep pendidikan qurban ini dapat mempengaruhi religiusitas siswa di SMP yang notabene siswanya memiliki keterbatasan materi dan latar belakang keluarga, maka akan lebih mudah untuk mempengaruhi religiusitas siswa di sekolah lain yang siswanya lebih mampu dan latar belakang keluarganya lebih baik.

\section{Landasan Teori}

\section{Qurban}

Padadasarnya, selainsebagairitualsunnahyangdiutamakanyang tentu hampir semua orang sudah mengerti,salah satu pesan utama ibadah qurban yang harus disampaikan adalah agar orang yang mampu dapat berbagi dengan orang yang berkekurangan, terutama dalam hal kesusahan atau miskin secara ekonomi. Sebagaimana disampaikan dalam Surat Al Hajj 28:

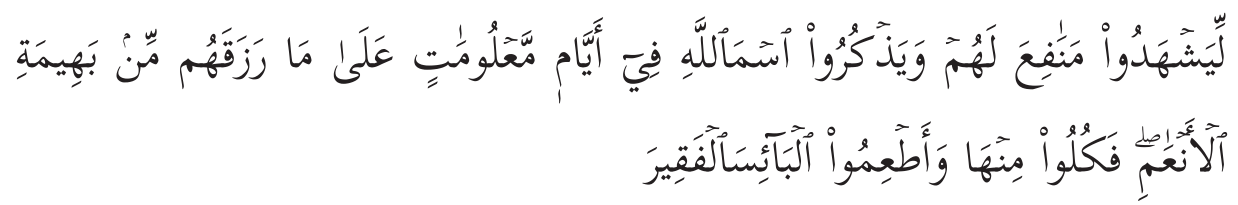

Supaya mereka menyaksikan berbagai manfaat bagi mereka dan supaya mereka menyebut nama Allah pada hari yang telah ditentukan atas rezki yang Allah telah berikan kepada mereka berupa binatang ternak. Maka makanlah sebahagian daripadanya dan (sebahagian lagi) berikanlah untuk dimakan orang-orang yang sengsara dan fakir (Al Hajj: 28).

Terkait dengan pendidikan qurban, ada beberapa nilai yang harus disampaikan kepada siswa, selain tata cara dan bagaimana berkurban, diantaranya adalah: 
1. Qurban merupakan bentuk kepatuhan kepada Allah

Latar belakang yang mendasari ritual qurban adalah dua kisah yang keduanya diceritakan di dalam Al Qur'an. Yang pertama adalah kisah Habil dan Qabil, seperti yang tertera didalam surat Al Maidah ayat 27:

"Ceritakanlah kepada mereka kisah kedua putera Adam (Habil dan Qabil) menurut yang sebenarnya, ketika keduanya mempersembahkan kurban, maka diterima dari salah seorang dari mereka berdua (Habil) dan tidak diterima dari yang lain (Qabil). Ia berkata (Qabil): “Aku pasti membunuhmu!”. Berkata Habil: "Sesungguhnya Allah hanya menerima (kurban) dari orang-orang yang bertakwa". (Al Maaidah: 27)

Kisah yang kedua adalah kisah kepasrahan dan ketaatan Nabi Ibrahim dan Nabi Ismail.Disebutkan dalam Al Qur'an, Allah memberi perintah melalui mimpi kepada Nabi Ibrahim untuk mempersembahkan Ismail. Diceritakan dalam Al Qur'an bahwa Ibrahim dan Ismail mematuhi perintah tersebut dan tepat saat Ismail akan disembelih, Allah menggantinya dengan domba. Berikut petikan surat Ash Shaaffaat ayat 102-107 yang menceritakan hal tersebut.

"Maka tatkala anak itu sampai (pada umur sanggup) berusaha bersama-sama Ibrahim, Ibrahim berkata: "Hai anakku sesungguhnya aku melihat dalam mimpi bahwa aku menyembelihmu. Maka fikirkanlah apa pendapatmu!" Ia menjawab: "Hai bapakku, kerjakanlah apa yang diperintahkan kepadamu; insya Allah kamu akan mendapatiku termasuk orang-orang yang sabar". Tatkala keduanya telah berserah diri dan Ibrahim membaringkan anaknya atas pelipis(nya), (nyatalah kesabaran keduanya), dan Kami panggillah dia: "Hai Ibrahim, sesungguhnya kamu telah membenarkan mimpi itu sesungguhnya demikianlah Kami memberi balasan kepada orang-orang yang berbuat baik. Sesungguhnya ini benar-benar suatu ujian yang nyata, dan Kami tebus anak itu dengan seekor sembelihan yang besar". (Ash Shaaffaat: 102-107) 
Kisah tentang Nabi Ibrahim dan Ismail ini mengajarkan bentuk kepasrahan dan ketaatan total kepada Allah SWT. Betapa hebatnya Nabi Ibrahim yang bersedia mengorbankan puteranya, yang untuk memperolehnya saja harus melalui penantian yang sangat lama. Lalu Nabi Ismail, betapa meski masih sangat muda, imannya begitu kokoh. Asal perintah itu datang dari Allah, maka ia tak meragukannya dan bersedia untuk disembelih.

2. Qurban mengajarkan arti berbagi

Salah satu syarat berqurban adalah membagikan $2 / 3$ bagian hewan yang diqurbankan untuk orang yang lain, yaitu $1 / 3$ dalam bentuk sedekah bagi yang membutuhkan, dan $1 / 3$ lainnya sebagai hadiah bagi orang lain (Minhaajul Muslim, 266). Hal ini tentunya syarat makna, yaitu lewat ibadah qurban, seorang manusia diajarkan untuk memangkas egonya hingga 2/3 dan membaginya dengan orang lain, terutama orang yang membutuhkan.

3. Qurban mengajarkan untuk bersyukur kepada Allah Yang Esa

Kembali pada kisah Nabi Ibrahim dan Ismail. Kisah tersebut menceritakan cobaan sedemikian dahsyat dari Allah SW'T yang harus mereka terima, yaitu persembahan seorang putra kesayangan. Dengan menghayati kisah tersebut, maka sudah selayaknya apabila umat Islam dapat mengambil pelajaran darinya dan lebih bersyukur karena cobaan yang diberikan dari Allah tidak harus seberat mengorbankan putra kesayangan.Oleh karenanya, kewajiban berqurban ini seharusnya dapat mengingatkan bahwa perintah berqurban hewan sembelihan belum ada apa-apanya dibandingkan dengan perintah yang diberikan Allah kepada Nabi Ibrahim untuk menyembelih putranya.

Selain itu, perintah berqurban juga mengandung makna bahwa sesungguhnya apabila Allah menghendaki, maka Allah dapat meminta dan mengambil apapun yang dimiliki oleh manusia saat ini.Karena segala sesuatu yang dimiliki manusia sejatinya merupakan pemberian dari Allah SW'T, dan hanya kepada Sang Pemilik-lah segala sesuatunya harus dikembalikan.Sehingga tidak ada alasan bagi manusia untuk tidak mensyukuri segala 
rahmat dan pemberian yang telah Allah berikan dan masih manusia miliki hingga saat ini.

\section{Tingkat Religiusitas Siswa (Remaja)}

Religiusitas atau keberagamaan merupakan pengertian mengenai seberapa jauh pengetahuan, seberapa kokoh keyakinan, seberapa pelaksanaan ibadah dan akidah, dan seberapa dalam penghayatan atas agama yang dianutnya. Bagi seorang muslim, religiusitas dapat diketahui dari seberapa jauh pengetahuan, keyakinan, pelaksanaan, dan penghayatan atas agama Islam. Dalam pelaksanaannya, keberagamaan merupakan gejala yang terbentuk dari berbagai unsur, dimana satu dan lainnya saling berkaitan untuk melahirkan satu kesatuan pengalaman beragama, yang kemudian akan memunculkan sikap keberagamaan (Musim, 2003).

Glock and Stark (1996) merupakan pemikir yang tulisannya banyak dirujuk oleh peneliti yang mengukur tingkat keberagamaan. Mereka menyatakan bahwa keberagamaan seseorang bisa dilihat dari 5(lima) dimensi, yaitu (1) pengalaman atau experiental(pengalaman pribadi dan pengalaman emosi keagamaan seperti ungkapan pribadi keagamaan); (2)ideologi (penerimaan terhadap sistem keyakinan); (3) ritual (berpartisipasi dalam kegiatan dan praktikkeagamaan); (4) intelektual (pengetahuan tentang sistem keyakinan); dan (5) konsekuensi (akibat-akibatetis dari keempat dimensi sebelumnya dan petunjuk yang diperoleh darinya).

Mengadopsi konsep barat(utamanya Glock dan Stark, 1965) dengan tetap berpijak pada ajaran Islam, Nafis, dkk (1995) mengembangkan konsep dimensi keberagamaan Islam yang merupakan perpaduan dari keempatdimensi, yaitu keimanan, komitmen, ritual, dan sosial. Dimensi keimanan mencakup keyakinan atau penerimaan subyek ataskebenaran ajaran agama Islam. Sedang dimensi komitmen mengacu pada kesediaan seseorang (muslim) menanggapi atau merespons ajaran Islam secara positif atau negatif. Dimensi ritual dan sosial mengacu pada intensitas kegiatan subyek dalam menjalankan perintah agama, khususnya masing-masing untuk ibadah kepada Allah (hablun min Allah) dan ibadah sosial (hablun min a-nās). 
Masa remaja menurut Thornburg yang dikutip oleh Agus Dariyo (2004) terbagi menjadi 3 tahap, yaitu masa remaja awal (usia 13- 14 tahun), remaja tengah (15-17tahun) remaja akhir (1821 tahun). Masa remaja awal, umumnya individu telah memasuki pendidikan dibangku sekolah menengah tingkat pertama(SLTP), sedangkan masa remaja tengah, individu telah duduk dibangku sekolah menengah atas (SMU), Kemudian yang tergolong dalam usia remaja akhir yaitu mereka yang umumnya sudah memasuki dunia perguruan tinggi atau lulus SMU ataupun yang sudah bekerja.

Ciri-ciri kesadaran beragama yang menonjol pada masa remaja ialah (Abdul Aziz Ahyadi, 2001):

1. Pengalaman ke-Tuhanan makin bersifat individual

Remaja makin mengenal dirinya, ia menemukan dirinya bukan hanyasekedar badan jasmaniyah, tetapi merupakan suatu kehidupan psikologi rohaniyah berupa pribadi. Keadaan labil yang menyebabkan remaja mencari ketentraman dan pegangan hidup menjadikan dia berpaling kepada'Tuhan sebagai satusatunya pegangan hidup.

2. Keimanannya makin menuju realitas yang sebenarnya

Dengan berkembangnya kemampuan berfikir secara abstrak, remajamampu pula menerima dan memahami ajaran agama yang berhubungandengan masalah gho ib, abstrak, dan rohaniyah, seperti kehidupan alam kubur,hari kebangkitan, surga, dan lain sebagainya. Penggambarannya tentangTuhan kemudian akan diganti dengan pemikiran yang lebih sesuai denganrealitas. Perubahan pemikiran itu melalui pemikiran yang lebih kritis.

3. Peribadatan mulai disertai penghayatan yang tulus

Kesadaran akan norma-normaagama berarti dia menghayati, menginternalisasikan dan mengintegrasikannorma tersebut dalam diri pribadinya sehingga menjadi bagian dari hati nuranidan pribadinya. Melalui kesadaran beragama dan pengalaman ke-Tuhanan, dia akan menemukan Tuhannya, yang berarti menemukan pribadinya. 


\section{Metode Penelitian}

Penelitian ini merupakan penelitian lapangan dimana pengumpulan datanya adalah dengan teknik kuesioner, observasi, interview, dokumentasi dan studi kepustakaan.Penelitian ini menggunakan siswa SMP Agus Salim kelas 7, 8 dan 9 sebagai obyek penelitian. Populasi penelitian ini adalah seluruh siswa kelas 7, 8 dan 9 SMP Agus Salim yang berjumlah 467 siswa. Sedangkan pengambilan sample dalam penelitian ini dilakukan menggunakan sistem Simple Random Sampling, yaitu sample diambil secara acak, tanpa ada kriteria tertentu dalam populasi.Penentuan sample dilakukan dengan menggunakan rumus:

$$
n=\frac{N}{1+N e^{2}}
$$

$$
\begin{aligned}
& \text { - } \mathrm{n}=\text { ukuran sampel } \\
& \text { - } \quad \mathrm{N}=\text { ukuran populasi } \\
& \text { - } \quad \text { e }=\text { nilai kritis (batas ketelitian) yg diinginkan(persen } \\
& \text { kelonggaran ketidaktelitian karenakesalahan } \\
& \text { pengambilan sampel) } \\
& \begin{array}{c}
n=\frac{467}{\left(1+\left(467 \times 0,1^{2}\right)\right)} \\
=82,36
\end{array}
\end{aligned}
$$

Sample yang diambil dalam penelitian ini adalah sebanyak 82 siswa yang terbagi dari siswa kelas 7, 8 dan 9 agar tiap-tiap kelas dapat terwakili.

Metode penelitian korelatif digunakan dalam penelitian ini untuk melihat adanya hubungan antara pendidikan tentang qurban kepada siswa dengan tingkat religiusitas atau keberagamaan siswa.Pendidikan tentang qurban yang dilakukan di SMP Agus Salim tercermin dari adanya program infaq siswa dengan tujuan mengumpulkan dana untuk berqurban bersama-sama pada hari Idul Adha, sedangkan tingkat religiusitas siswa diukurnya dengan menggunakan empat dimensi seperti yang dikembangkan Nafis, dkk (1995), yaitu keimanan, komitmen, ritual dan sosial. 


\section{Analisis}

Kegiatan pendidikan Islami di SMP Agus Salim

SMP Agus Salim merupakan sekolah menengah pertama yang ada di bawah naungan Yayasan Agus Salim.Berdiri sejak tahun 1987, salah satu concern dari SMP Agus Salim adalah memberikan pendidikan yang Islami.Sesuai dengan visi yang dimilikinya yaitu menjadikan anak didiknya sebagai generasi yang berkarakter, berilmu dan berwawasan luas.Dalam rangka mewujudkan visi tersebut, SMP Agus Salim berkomitmen untuk selalu menyelenggarakan pendidikan berbasis Islami, beberapa contoh pengeja-wantahan visi ini adalah dengan diselenggarakannya kegiatan-kegiatan Islami seperti (1).Sebelum kegiatan belajar mengajar dilaksanakana, siswa diminta untuk berdoa bersama, membaca Syahadat, Asmaul Husna dan Shalawat Nariyah, (2).Siswa diwajibkan untuk ikut sholat Dhuha dan Dzuhur bersama-sama, serta bagi siswa laki-laki wajib untuk mengikuti sholat Jum'at bersama, (3). Setiap hari Jumat, secara sukarela siswa diminta untuk memberikan infaq, dimana dana yang diperoleh akan digunakan untuk berlatih qurban bersama-sama, (4). Pada hari setelah kelulusan, siswa kelas 9 diajak bersama-sama untuk mengunjungi yayasan social, seperti panti asuhan atau panti jompo, (5).Pelajaran Agama Islam dilaksanakan seminggu dua kali, dua jam pelajaran per pertemuannya. Pada saat pelajaran Agama Islam, siswa diajarkan untuk mengaji Iqra' dan hafalan surat-surat pendek, juz 30, surat 86-114.

Kegiatan-kegiatan yang dilakukan SMP Agus Salim sebagai bentuk pendidikan Islami tadi apabila dihubungkan dengan indicator keberagamaan Nafis, dkk (1995), telah memenuhi keempatnya, yaitu keimanan, komitmen, ritual dan social.Indikator keimanan mencakup keyakinan atau penerimaan subyek ataskebenaran ajaran agama Islam.Diwujudkan dalam bentuk siswa diminta untuk mengucap syahadat bersama. Didalam Islam, syahadat merupakan ruh, inti dan landasan dari keseluruhan agama Islam, sehingga bagi pemeluknya, merupakan hal mutlak untuk mengucapkannya dan mengimaninya. Melalui pembacaan syahadat setiap hari, siswa diajak untuk selalu memperbarui keimanannya dan terus menerus meyakini bahwa tiada Tuhan selain Allah dan Muhammad merupakan rasul Allah. 
Indikator komitmen mengacu pada kesediaan seseorang (muslim) menanggapi atau merespons ajaran Islam secara positif atau negatif. Indikator komitmen akan dilihat dari kesediaan siswa untuk menjalani agamanya (Islam) dengan sukarela atau tidak. SMP Agus Salim juga telah menerapkan dimensi komitmen ini, yaitu dengan tidak menyediakan presensi pada setiap kegiatan keagamaan, seperti sholat Dhuha, Dzuhur dan Jum'at, walaupun ketiganya diwajibkan. Hal ini dilakukan untuk menumbuhkan kesadaran serta komitmen pribadi dari masing-masing siswa dalam menjalani agamanya.

Indikator ritual mengacu pada intensitas kegiatan subyek dalam menjalankanperintah agama, khususnya masing-masing untuk ibadah kepadaAllah (hablun min Allah). Diwujudkan dalam bentuk ibadah-ibadah yang sifatnya ritual, seperti sholat Dhuha, Dzuhur dan Jum'at berjamaah, membaca Asmaul Husna, Sholawat Nariyah, mengaji dan hafalan surat-surat pendek. Selain itu, setiap hari Idul Fitri dan Idul Adha, SMP Agus Salim juga menyelenggarakan sholat Ied yang dapat diikuti oleh siswa maupun masyarakat sekitar.

Indikator sosial merupakan intensitas kegiatan subyek dalam menjalankan perintah agama, khususnya yang hubungannya dengan sesama manusia (hablun min annas).Dicerminkan lewat kegiatan infaq sukarela setiap hari Jum'at dan kunjungan ke panti asuhan. Pada saat siswa diminta untuk berinfaq, siswa diberi pengertian bahwa uang infaq yang terkumpul akan digunakan untuk sedekah hewan qurban pada saat hari raya Idul Adha, lebih dari itu siswa juga diberi pemahaman bahwa qurban itu memiliki banyak makna.

Makna yang pertama adalah siswa diajarkan arti berbagi melalui berqurban, bahwasanya walaupun mayoritas dari siswa SMP Agus Salim merupakan siswa dari golongan ekonomi menengah ke bawah, namun mereka juga dapat merasakan pengalaman untuk berbagi dengan sesama lewat sedekah hewan qurban. Lebih lanjut siswa juga diajarkan untuk memahami kisah nabi Ibrahim dan Ismail yang melatarbelakangi prosesi qurban.Selain itu siswadibuat untuk dapat memahami qurban sebagai bentuk rasa syukur kepada Allah SWT.Penyembelihan hewan qurban dilaksanakan dengan melibatkan seluruh guru, siswa dan masyarakat sekitar. Hasil dari hewan qurban yang terkumpul akan dibagikan kembali untuk para siswa dan masyarakat kurang mampu di sekitar Agus Salim. 
Kegiatan pengamalan dimensi sosial yang selanjutnya adalah kunjungan ke panti asuhan pada hari kelulusan. Fenomena merayakan kelulusan dengan kebut-kebutan dijalan dan mencoretcoret baju seragam adalah fenomena yang tidak asing ditemui pada remaja masa kini. SMP Agus Salim mencoba untuk mengajarkan siswa mensyukuri kelulusan dengan cara yang benar, yaitu dengan melibatkan hati untuk seutuhnya bersyukur kepada Allah serta dengan cara berbagi kepada orang-orang yang lebih membutuhkan. Dengan mengunjungi panti asuhan, diharapkan siswa Agus Salim yang mayoritas berasal dari golongan ekonomi menengah kebawah dapat menyadari, bahwa sesungguhnya kondisi mereka jauh lebih baik dibanding dengan anak-anak yatim piatu itu, agar supaya mereka bersyukur.

\section{Persepsi Siswa Terhadap Pendidikan Qurban di Sekolah}

Pendidikan mengenai ibadah qurban telah diterapkan sejak kelas 7 hingga kelas 9 di SMP Agus Salim dengan pemahaman yang diberikan berulang setiap Jum'at saat ketua kelas dari masingmasing kelas bertugas untuk mengumpulkan infaq siswa. Dalam penelitian ini, persepsi siswa mengenai pendidikan qurban diteliti melalui kuesioner dengan enam pertanyaan tertutup yang disusun dengan model Likert's Summated Rating (LSR).Enam pertanyaan tersebut bermaksud untuk melihat pemahaman, penghayatan serta keikhlasan siswa dalam melaksanakan latihan sedekah qurban.

Dari 82 responden yang menjadi sample, diketahui bahwa mean adalah 3.04, dalam arti rata-rata responden setuju (3) hingga sangat setuju (4) dengan pertanyaan-pertanyaan yang diberikan. Dengan arti lain, mayoritas siswa dapat memahami, menghayati dan ikhlas dalam melaksanakan latihan sedekah qurban.Berikut adalah gambaran statistic deskriptif dari persepsi siswa mengenai pendidikan qurban:

\begin{tabular}{cc}
\hline \multicolumn{2}{c}{ Column1 } \\
\hline Mean & 3.04065 \\
Standard Error & 0.082492
\end{tabular}




$\begin{array}{cc}\text { Median } & 3.333333 \\ \text { Mode } & 3.5 \\ \text { Standard Deviation } & 0.746993 \\ \text { Sample Variance } & 0.557998 \\ \text { Range } & 3 \\ \text { Minimum } & 1 \\ \text { Maximum } & 4 \\ \text { Sum } & 249.3333 \\ \text { Count } & 82 \\ \text { Largest }(1) & 4 \\ \text { Smallest(1) } & 1 \\ \text { Confidence } & 0.164132 \\ \text { Level(95.0\%) }\end{array}$

Tabel 1.

Statistik Deskriptif Persepsi Siswa Terhadap Pendidikan Qurban

Setelah kuesioner disebarkan, dianalisis dan didapatkan hasilnya, analisa lanjutan dilakukan, yaitu dengan melakukan interview pada wali kelas dan kepala sekolah mengenai hasil kuesioner. Interview ini dilakukan untuk memastikan kevalidan hasil kuesioner apabila dilihat dari sisi kualitatif subyektifnya. Hasil interview pada guru agama dan kepala sekolah ternyata menunjukkan hasil yang selaras dengan hasil analisis kuesioner. Mereka menyatakan sepakat, apabila dikatakan siswanya mayoritas memahami, menghayati dan ikhlas dalam melakukan latihan sedekah kurban. Hal ini dapat terwujud dikarenakan konsistensi dari para guru dan kepala sekolah untuk tidak lelah memberikan penjelasan kepada siswa mengenai manfaat dan hakikat berqurban, ditambah lagi adanya harapan dari para siswa di hari Idul Adha nanti mereka juga ikut mendapatkan bagian dari hewan sembelihan yang dibagikan, baik bagian berupa daging maupun bagian berupa pahala. 


\section{Tingkat Religiusitas Siswa}

Pengukuran tingkat religiusitas siswa pada penelitian ini didasarkan pada dimensi yang dikemukakan oleh Nafis (1995), yaitu dimensi keyakinan, komitmen, ritual dan sosial. Dimensi keyakinan dan komitmen merupakan dimensi mental atau psikologis yang secara kasat mata tidak dapat dilihat maupun dirasa oleh panca indera. Berbeda dengan dimensi ritual dan sosila yang pencerminannya dapat dilihat dari perilaku seseorang. Oleh karenanya, kuesioner yang dibagikan, mencantumkan 20 pertanyaan yang dibagi menjadi 10 pertanyaan dimensi mental, dan 10 pertanyaan berdimensi perilaku.

Pertanyaan yang berdimensi mental atau psikologis memuat konten mengenai apakah responden memiliki keimanan terhadap enam hal yang tercantum dalam rukun iman, serta apakah mereka bersedia untuk melakukan perbuatan baik serta menghindari perbuatan buruk dikarenakan keimanan yang mereka pegang tersebut. Hasil deskriptif dari data mengenai tingkat religiusitas siswa tergambar dalam table dibawah ini:

\begin{tabular}{cc}
\hline \multicolumn{2}{c}{ Column1 } \\
\hline Mean & 2.982927 \\
Standard Error & 0.079667 \\
Median & 3.2 \\
Mode & 3.5 \\
Standard Deviation & 0.721419 \\
Sample Variance & 0.520446 \\
Range & 2.8 \\
Minimum & 1.2 \\
Maximum & 4 \\
Sum & 244.6 \\
Count & 82
\end{tabular}


Largest(1) 4

Smallest(1) $\quad 1.2$

Confidence

Level(95.0\%)

0.158513

Tabel 2.

\section{Statistik Deskriptif Tingkat Religiusitas Siswa}

Hasil statistik deskriptif mengenai tingkat religiusitas siswa SMP Agus Salim menunjukkan hasil yang cukup baik, dengan mean 2,98 dapat diartikan mayoritas siswa hampir setuju (antara level kurang setuju (2) dengan setuju (3)) akan pertanyaan-pertanyaan yang diberikan. Range yang tercipta cukup besar yaitu diangka 2,8, yang berarti mencerimkan kesenjangan yang cukup jauh antara siswa yang memiliki tingkat religiusitas tinggi dengan siswa yang sebaliknya.

Analisa lanjutan pun dilakukan dengan melakukan interview pada guru agama dan kepala sekolah, ternyata dari hasil interview diperoleh fakta bahwa memang terdapat kesenjangan tingkat religiusitas yang tinggi pada siswa-siswanya.Hal ini dapat terjadi karena dipengaruhi oleh banyak faktor, baik faktor intern maupun faktor ekstern.

Faktor-faktor yang mempengaruhi tingkat religiusitas siswa antara lain faktor internal seperti (1). Peranan konflik moral, yaitu antara apa yang dia ketahui dengan kenyataan yang terjadi, (2). kebutuhan-kebutuhan dan keinginan-keinginan yang antar satu individu dengan individu lainnya berbeda-beda, (3). Faktor penalaran verbal, yaitu faktor yang dimainkan oleh pemikiran, karena manusiadilahirkan sebagai mahkluk berfikir, salah satu akibat dari pemikirannyaadalah bahwa ia membantu dirinya untuk menentukan keyakinan-keyakinanmana yang harus diterima dan mana yang harus ditolak.

Faktor eksternal juga memerankan peran yang tidak kalah penting dalam memengaruhi tingkat religiusitas seseorang, antara lain adalah: (1). Faktor lingkungan keluarga, (2). Lingkungan pergaulan atau pertemanan dan, (3). Lingkungan masyarakat. 
Korelasi Antara Pendidikan Qurban Dengan Tingkat Religiusitas Siswa

Tujuan dasar pendidikan agama adalah untuk mendidik umat manusia, dan mengembangkan kecenderungan spiritual dan moral dalam diri mereka.Semakin dini pendidikan agama ditanamnkan ke dalam diri anak-anak, maka akan semakin baik pula hasil yang diharapkan akan diperoleh. SMP Agus Salim menyadari hal ini, oleh karenanya, walaupun bukan merupakan sekolah Islam terpadu, namun SMP Agus Salim meletakkan prinsip dasar pendidikannya berlandaskan ajaran agama Islam untuk menghasilkan anak didik yang religious. Begitu pula pendidikan mengenai ibadah qurban yang dimulai dengan pelatihan sedekah qurban dilakukan dan diharapkan ada korelasinya dengan tingkat religiusitas siswa SMP Agus Salim. Melalui analisa regresi dan korelasi, berikut adalah hasil yang diperoleh:

\begin{tabular}{cc}
\hline \multicolumn{2}{c}{ Regression Statistics } \\
\hline Multiple R & 0.946692 \\
R Square & 0.896227 \\
Adjusted R & 0.894929 \\
Square & \\
Standard Error & 0.233845 \\
Observations & 82 \\
\hline
\end{tabular}

\section{Table 3.}

\section{Hasil Regresi Pendidikan Qurban pada Tingkat Religiusitas Siswa}

Hasil statistic regresidiatas menunjukkankoefisien determinasi $\left(\mathrm{R}^{2}\right)$ yang cukup besar yaitu $89 \%$, yang berarti bahwa pendidikan qurban ini mempengaruhi tingkat religiusitas siswa dengan cukup besar. Hal ini membuktikan bahwa pendidikan teramat sangatlah penting dalam membentuk seseorang menjadi lebih baik, termasuk dalam hal ini, pendidikan agama dapat membentuk seseorang untuk lebih religious. Bukan hanya dalam menjalankan ritual atau syariatnya saja, melainkan juga dengan mengimani dalam hati, meniatkan diri untuk berkomitmen dengan ajaran agamanya, serta menjalankan bablun min Allab dan hablun min annas. 


\begin{tabular}{cccccc}
\hline \multicolumn{5}{c}{ ANOVA } \\
\hline & $d f$ & $S S$ & $M S$ & $F$ & Significance F \\
\hline Regression & 1 & 37.78141 & 37.78141 & 690.9102 & $4.13 \mathrm{E}-41$ \\
Residual & 80 & 4.374683 & 0.054684 & & \\
Total & 81 & 42.1561 & & & \\
\hline
\end{tabular}

Tabel 4.

Hasil Uji ANOVA

Tabel ANOVA (Analysis of Variance) menguji penerimaan (acceptability) model dari perspektif statistik dalam bentuk analisis sumber keragaman. ANOVA ini sering juga diterjemahkan sebagai analisis ragam. Dari tabel ANOVA tersebut diungkapkan bahwa keragaman data aktual variabel terikat bersumber dari model regresi dan dari residual. F hitung 690, 9102 lebih besar dari F table, yang mengartikan bahwa terdapat korelasi yang kuat antara variable bebas dengan variable terikat. Pendidikan qurban punya pengaruh signifikan terhadap tingkat religiusitas siswa.

\begin{tabular}{ccccccc}
\hline & Coefficients & $\begin{array}{c}\text { Standard } \\
\text { Error }\end{array}$ & t Stat & P-value & $\begin{array}{c}\text { Lower } \\
95 \%\end{array}$ & $\begin{array}{c}\text { Upper } \\
95 \%\end{array}$ \\
\hline $\begin{array}{c}\text { Intercept } \\
\begin{array}{c}\text { Pendidikan } \\
\text { Qurban }\end{array}\end{array}$ & 0.202914 & 0.108871 & 1.86381 & 0.066017 & -0.01375 & 0.419573 \\
\hline
\end{tabular}

Tabel 5.

Koefisien Regresi

Hasil koefisien regresi menunjukkan dengan tingkat kepercayaan 95\%, maka koefisien regresi untuk pendidikan qurban sebesar 0.914282 , dalam faktanya di tingkat populasi akan berkisar antara 0.845062 - 0.983503. t hitung $>$ t table menunjukkan indikasi bahwa variable pendidikan qurban memiliki pengaruh positif signifikan dengan kenaikan tingkat religiusitas siswa. 


\section{Kesimpulan}

Hasil yang dapat disimpulkan dari penelitian ini adalah bahwa SMP Agus Salim telah melaksanakan amanat pendidikan dengan baik, terutama pada bidang pendidikan agama, lebih khusus lagi adalah pendidikan mengenai ibadah qurban. Pendidikan qurban yang dilaksanakan dengan teknik pelatihan sedekah qurban, dirasa cukup efektif untuk menanamkan pada diri anak didik mengenai pentingnya berbagi dan berqurban.

Mayoritas siswa dianggap dapat memahami, menghayati dan ikhlas dalam melaksanakan pelatihan sedekah qurban, hanya saja yang ditemukan dalam penelitian ini adalah adanya kesenjangan yang cukup luas antara siswa yang memiliki tingkat religiusitas tinggi dengan yang sebaliknya. Hal ini rupanya terjadi karena adanya faktor-faktor baik internal maupun eksternal. Namun, setelah adanya penelaahan lebih lanjut, ternyata faktor eksternal memegang peranan yang lebih besar, barangkali karena penelitian dilakukan dengan obyek siswa SMP yang termasuk ke dalam golongan remaja, yang jiwanya masih labil. Sehingga dengan kondisi jiwa yang masih labil ini, sangat mudah sekali bagi faktor di luar diri untuk berperan besar dalam pengambilan setiap keputusannya.

Lebih lanjut penelitian ini diharapkan dapat memberikan kontribusi bagi perkembangan pendidikan Islam, terutama pendidikan yang sifatnya praktis, bukan hanya teoritis. Penelitian ini dapat membuktikan bahwa pendidikan yang bersifat praktis (pelatihan sedekah qurban) dan bukan teoritis, ternyata melekat lebih erat pada benak siswa, dan sedikit banyak memperngaruhi moral serta tingkat keberagamaan siswa.

\section{Daftar Pustaka}

Nafis, M., \& Kawan-kawan. 1995.Keberagamaan Masyarakat Muslim Kodia Semarang, Semarang: Pusat Penelitian IAIN WalisongoSemarang.

H, Musim A.Kadir.2003.Ilmu Islam Terapan(mengagas Paradigma Amali dalam Agama Islam), Yogyakarta: Pustaka Pelajar 
Agoes Dariyo. 2004.Psikologi Remaja, Bogor: Ghalia Indonesia, hlm 14

Glock, C.Y. \& Stark, R. (1996).Cristen beliefs and anti-semitism.New York: Harper \& Row

Rasyid, Sulaiman. 2012.Fiqih Islam, Bandung: Sinar Baru Algensindio

http://muslim.or.id/fiqh-dan-muamalah/fiqih-qurban.html

Syafaat, Aat. 2008.Peranan Pendidikan Islam Dalam Mencegah Kenakalan Remaja (Juvenile Deliquency), Jakarta: Raja Grafindo Persada.

Dajan, Anto. 1995. Pengantar Statistik I, Jakarta: LP3ES

http://www.pewforum.org/files/2009/10/Muslimpopulation.pdf

Vatikiotis, P. J. "MuḥAmmad 'Abduh and the quest for a Muslim Humanism." Arabica 4.1 (1957): 55-72. 